\title{
Appendix D: North Atlantic merchants from Bremen in the sixteenth century
}

Sources: SAB 2-ad P.9.c.A.1.Nr.1: overview of eldermen of the gemene kopman; SAB 2-R.11.ff.: complaints against Harmen Oldensche in Hólmur, 9 December 1548 (15481209BRE00); maschup contract 8 April 1549 (15490408BRE00); maschup contract 16 April 1572 (15720416BRE00); final plea of Bernd Losekanne against Christoffer Meyer, 1576 (15760200BRE00); SAB 2-R.11.gg.1.: overview of eldermen and Frachtherren of the society of Bergen merchants, 1550-1679; SAB 2-R.11.kk.: obligation of Gerdt Breker, September 1557 (15570900SHE00); witness accounts about the sale of a maschup, 14 May 1557 and 4 May 1575 (15570514BRE00; 15750504BRE00); complaints of Johan Runge about the interference of Segebad Detken in Baltasound, 26 October 1562 (15621026BRE00); SAB 2-R.11.p.3.b.2. Bd. 1: register of sea passes 1592-1621; RAK D11 Pakke 26: testimonies of old Bremen men about the harbour Berufjörður, 3 December 1590 (15901203BRE00); SD 1195-1579, no. 158; CBS 1602-1604. The court book provides many more names of German merchants, but these are often hard to identify, or their home towns are not mentioned. Supplementary sources have been indicated in the footnotes.

Abbreviations: BF: member of the Bergenfahrer society / HS: elderman of Haus Seefahrt / E: elderman of the gemene kopman / C: councillor / B: burgomaster.

Iceland merchants

\begin{tabular}{llll}
\hline Name & Career in Iceland & Licences & Other \\
\hline Alberts, Heinrich & 1597 merchant or shipowner in & $1596-1601$ & \\
& Stykkishólmur & Stykkishólmur & \\
& 1592-1594 sea passes for a "bott” of 50 & \\
& lasts named de Jeger & \\
\hline
\end{tabular}

1 SAB 2-R.11.ff.; RAK D11, Pakke 25: Request to sail to Stykkishólmur, 20 April 1597 (15970420BRE00).

Ә Open Access. () 2020 Bart Holterman, published by De Gruyter. (cc) BY-NC-ND This work is licensed under a Creative Commons Attribution-NonCommercial-NoDerivatives 4.0 International License.

https://doi.org/10.1515/9783110655575-014 
Iceland merchants (continued)

\begin{tabular}{|c|c|c|c|}
\hline Name & Career in Iceland & Licences & Other \\
\hline $\begin{array}{l}\text { Bake, Carsten } \\
\text { father: Vasmer }\end{array}$ & $\begin{array}{l}<c .1582 \text { merchant in Nesvogur, then } \\
\text { Flatey; } 1590-1592 \text { Hólmur in } \\
\text { partnership with Luder Ottersen from } \\
\text { Lübeck; }^{2} 1593-c .1600 \text { sheriff in }^{3} \\
\text { Arnarstapi / Snæfellsnes }\end{array}$ & $\begin{array}{l}1586-1589 \\
\text { Flatey } \\
1590-1592 \\
\text { Hólmur } \\
\text { 1593-1595 } \\
\text { Nesvogur, } \\
\text { Landey }\end{array}$ & \\
\hline Bake, Vasmer & $\begin{array}{l}\text { c.1528-1580s merchant in Nesvogur, } \\
\text { Kumbaravogur, Arnarstapi and Búdir } \\
\left(1570^{4}-1580 \text { s), lost a ship in the latter }\right. \\
\text { harbour }^{5}\end{array}$ & & \\
\hline Boleman, Bernt & c.1548 in Hólmur & & \\
\hline $\begin{array}{l}\text { Bornhorst, } \\
\text { Christoffer }\end{array}$ & 1570-1571 merchant in Búðir 6 & & \\
\hline Boske, Boske & c. 1548 in Hólmur & & \\
\hline Brockman, Hinrich & $\begin{array}{l}1600 \text { merchant in Iceland }^{7} \\
1594,1597 \text { sea passes for a "bott" of } \\
32 / 40 \text { lasts }\end{array}$ & & \\
\hline $\begin{array}{l}\text { Brockman, Jost } \\
\text { born c. } 1496\end{array}$ & c. 1511 first in Berufjörður as gunner & & \\
\hline Buerman, Herman & 1532 skipper in Iceland (Hólmur?) ${ }^{8}$ & & \\
\hline $\begin{array}{l}\text { Dranteman, Clawes } \\
\text { Dreyer, Gerdt }\end{array}$ & $\begin{array}{l}1600 \text { merchant in Iceland }^{9} \\
1594 \text { skipper? in } \\
\text { Búdir and Nesvogur }^{10}\end{array}$ & & \\
\hline
\end{tabular}

2 RAK D11, Pakke 25: Request of Carsten Bake for a licence for Nesvogur and Kumbaravogur, 28 February 1593 (15930228BRE01)

3 See Section 4.4.1.1.

4 SAB 2-R.11.ff.; RAK D11, Pakke 25: Complaints against Hamburg merchants in Búðir, 23 September 1570 and 23 January 1571 (15700923BRE00, 15710123BRE00)

5 RAK D11, Pakke 25: Request of Carsten Bake for a licence for Nesvogur and Kumbaravogur, 28 February 1593 (15930228BRE01)

6 SAB 2-R.11.ff.; RAK D11, Pakke 25: Complaints against Hamburg merchants in Búðir, 23 September 1570 and 23 January 1571 (15700923BRE00, 15710123BRE00)

7 SAB 2-R.11.ff.: Testimonies about weights in Iceland, 30 December 1600 (16001230BRE00).

8 DI 16:302.

9 SAB 2-R.11.ff.: Testimonies about weights in Iceland, 30 December 1600 (16001230BRE00).

10 SAB 2-R.11.ff.: Complaint of Carsten Bake against Dreyer, 25 July 1595 (15950725ARN00). 
Iceland merchants (continued)

\begin{tabular}{|c|c|c|c|}
\hline Name & Career in Iceland & Licences & Other \\
\hline Durkop, Radtke & 1532 skipper in Iceland (Hólmur?) ${ }^{11}$ & & \\
\hline Eddelman, Johan & c. 1548 in Hólmur & & \\
\hline Egeler, Berendt & $\begin{array}{l}1597 \text { merchant or shipowner in } \\
\text { Stykkishólmur }{ }^{12}\end{array}$ & & \\
\hline Falenkamp, Berent & 1558 in Kumbaravogur? ${ }^{13}$ & & \\
\hline Ficken, Clawes & $<1557$ merchant in Kumbaravogur $^{14}$ & & \\
\hline Frese, Folckert & 1549 member of maschup in Berufjörður & & \\
\hline $\begin{array}{l}\text { Gerbade, Gerdt } \\
\text { died } 1600\end{array}$ & $\begin{array}{l}1597 \text { merchant or shipowner in } \\
\text { Stykkishólmur }{ }^{15} \\
\text { see also Shetland }\end{array}$ & & E 1568 \\
\hline Gerdes, Roleff & $\begin{array}{l}1577 \text { chartered by Jurgen Thim from } \\
\text { Hamburg } \\
1580 \text { chartered by Joachim Kolling }^{16} \\
\text { (Hooksiel/Oldenburg) to sail to } \\
\text { Kumbaravogur } \\
1580 \text { s? sailed to Landey near } \\
\text { Kumbaravogur }{ }^{18} \\
1592 \text { Sea pass for a "rasegel" of } 40 \text { lasts } \\
\text { named dat Mehrwif, } 1599 \text { for a "kraffell" } \\
\text { of } 30 \text { lasts named de Valcke }\end{array}$ & & \\
\hline Grascher, Wolder & c. 1548 in Hólmur & & \\
\hline $\begin{array}{l}\text { Haneman, Hans } \\
\text { died } 1522\end{array}$ & 1522 skipper in Kumbaravogur ${ }^{19}$ & & \\
\hline
\end{tabular}

11 DI 16:302.

12 SAB 2-R.11.ff.; RAK D11 Pakke 25: Complaint against Oldenburg merchants in Stykkishólmur, 2 November 1597 (15971102BRE00).

13 Appears in the debt book of Clawes Monnickhusen (no. 127). Hofmeister, "Schuldbuch (2001)", 30. 14 SAB 7,2051: Account book of Clawes Monnickhusen (15570000BRE00).

15 SAB 2-R.11.ff.; RAK D11, Pakke 25: Request to sail to Stykkishólmur, 20 April 1597 (15970420BRE00).

16 SAB 2-R.11.ff.: Complaint of Jurgen Thim against Roleff Gerdes, 19 March 1577 (15770319HAM00).

17 SAB 2-R.11.ff.; NLO Best. 20, -25, no. 6: Complaint of Joachim Kolling against Bremen, 6 April 1580 (15800406OLD00).

18 SAB 2-R.11.ff.; RAK D11, Pakke 25: Request to sail to Stykkishólmur, 20 April 1597 (15970420BRE00).

19 DI 16:268 (15231103BRE00). 
Iceland merchants (continued)

\begin{tabular}{|c|c|c|c|}
\hline Name & Career in Iceland & Licences & Other \\
\hline Harst, Johan & $\begin{array}{l}1572 \text { partner in maschup in Berufjördur } \\
\text { (stays at home) }\end{array}$ & & \\
\hline Hegewisch, Cordt & Merchant in Hólmur until c. 1548 & & \\
\hline Holste, Henrick & 1552 skipper in Búðir ${ }^{20}$ & & \\
\hline Honne, Hans & $\begin{array}{l}1594 \text { skipper in Nesvogur }{ }^{21} \\
1592-1598 \text { sea passes for a "kraffel" of } \\
50 \text { lasts, } 1600 \text { for a "kraffel" of } 30 \text { lasts } \\
\text { named de Valcke }\end{array}$ & & \\
\hline Hoveman, Evert & c. $1567-1584$ merchant in Nesvogur ${ }^{22}$ & & HS 1592 \\
\hline Hudeman, Johan & 1570-1571, 1587 merchant in Búdir ${ }^{23}$ & $\begin{array}{l}\text { 1567-1601 } \\
\text { Búdir }\end{array}$ & \\
\hline Hudeman, Wilcken & 1526 merchant in Búdir ${ }^{24}$ & & \\
\hline Jonsson, Björn & 1589 partner of Páll Jónsson in Flatey ${ }^{25}$ & $\begin{array}{l}1594-1596 \\
\text { Flatey }\end{array}$ & \\
\hline $\begin{array}{l}\text { Kenckel, Detmar } \\
\text { died } 19-2-1584 \text {, } \\
\text { aged } 71\end{array}$ & $\begin{array}{l}\text { merchant in Arnarstapi }{ }^{26} \\
1567 \text { has outstanding debts for Icelandic } \\
\text { stockfish in Verden }^{27}\end{array}$ & & $\begin{array}{l}\text { C } 1549 \\
\text { В } 1554-1562\end{array}$ \\
\hline Kinkel & 1502 merchant in Arnarstapi ${ }^{28}$ & & \\
\hline Knippe, Johan & Merchant in Hólmur until c. 1548 & & \\
\hline
\end{tabular}

20 DI 12:323.

21 NLO Best. 20, -25, no. 6, Oldenburg complaint about Hans Honne in Nesvogur, 26 August 1594 (15940826OLD00).

22 SAB 2-R.11.ff.: Instruction for Heinrich Bredelo, 18 January 1588 (15880118BRE00).

23 SAB 2-R.11.ff.; RAK D11, Pakke 25: Complaints against Hamburg merchants in Búðir, 1570, 1571 (15700923BRE00, 15710123BRE00), complaints against English pirates, December 1587 (15871200BRE00).

24 SAB 2-R.11.ff.: Instruction for Heinrich Bredelo, 18 January 1588 (15880118BRE00).

25 RAK D11 Pakke 25: Declaration of Pall Jonsson, 28 September 1589 (15890928KOB00).

26 RAK D11 Pakke 25: Letter of his son Detmar Kenckel to Bremen, 7 September 1591 (15910907BRE00).

27 Smidt, “Aus Detmar Kenckel's Nachlass”, 30.

28 DI 8:76; DN 16:338: Bergen complaints about the Icelandic trade, 1502. The document does not make clear whether he was from Bremen. 
Iceland merchants (continued)

\begin{tabular}{|c|c|c|c|}
\hline Name & Career in Iceland & Licences & Other \\
\hline Kock, Hans & $\begin{array}{l}1527 \text { skipper in Iceland, appears at the } \\
\text { Althing }{ }^{29}\end{array}$ & & \\
\hline Kock, Luder & 1552 skipper in Grindavík ${ }^{30}$ & & \\
\hline $\begin{array}{l}\text { Korffmacher, } \\
\text { Heinrich }\end{array}$ & $\begin{array}{l}\text { Freighted ships to Berufjörður before } \\
1549\end{array}$ & & \\
\hline Koster, Albert & $\begin{array}{l}1597 \text { merchant or shipowner in } \\
\text { Stykkishólmur }{ }^{31}\end{array}$ & & \\
\hline Koster, Friedrich & $\begin{array}{l}\text { 1587, c. } 1593-1595 \text { merchant in } \\
\text { Nesvogur }\end{array}$ & $\begin{array}{l}\text { 1592-1594 } \\
\text { Búdir }\end{array}$ & \\
\hline Koster, Johan & $\begin{array}{l}\text { 1583-1585 shipowner or merchant in } \\
\text { Nesvogur }\end{array}$ & & \\
\hline Kote/Rote, Albert & & $\begin{array}{l}\text { 1596-1601 } \\
\text { Stykkishólmur }\end{array}$ & \\
\hline Krechting, Herman & $\begin{array}{l}\text { merchant in Grindavík/Keflavík, tried to } \\
\text { acquire a licence in } 1566^{34}\end{array}$ & & \\
\hline Lanthrede, Johan & merchant in Hólmur until c. 1548 & & \\
\hline Lehe, Hinrich von & $\begin{array}{l}1600 \text { merchant in Snæfellsnes }{ }^{35} \\
1604 \text { sea pass for a "both" of } 50 \text { lasts } \\
\text { named de Rode Lowe }\end{array}$ & & \\
\hline
\end{tabular}

29 DI 9:343, version C: Copy of Althing verdict written in Skálholt, July 5, 1527. According to version B, written in Pingvellir, as well as in the Low German translation (SAH 111-1 Islandica, vol. 2), Hans Kock is mentioned among the Hamburg merchants (15270702ISL00). 30 DI 12:323.

31 SAB 2-R.11.ff.; RAK D11, Pakke 25: Request to sail to Stykkishólmur, 20 April 1597 (15970420BRE00).

$32 \mathrm{SAB}$ 2-R.11.ff.: Complaint to Queen Elizabeth of England about English pirates, 27 February 1588 (15880227BRE00); Carsten Bake requests a prolongation of the licence for Nesvogur, 25 July 1595 (15950725ARNO0).

33 SAB 2-R.11.ff.: Request for mediation by the archbishop, 27 September 1583 (15830927BRE00); Verdict of the Bremen city council, 3 February 1585 (15850203BRE00)

34 RAK D11, Pakke 25; SAB 2-R.11.ff.: Request for licences, 6 September 1565 and 29 March 1566 (15650906BRE00; 15660329BRE00).

35 SAB 2-R.11.ff.: Testimonies about weights in Iceland, 30 December 1600 (16001230BRE00). 
Iceland merchants (continued)

\begin{tabular}{|c|c|c|c|}
\hline Name & Career in Iceland & Licences & Other \\
\hline $\begin{array}{l}\text { Losekanne, Bernd } \\
\text { born c. } 1511 \\
\text { Father: } \text { Marten }^{36}\end{array}$ & $\begin{array}{l}\text { from c. } 1531 \text { sailor; } 1549,1567-1569 \text {, } \\
1572, \text { c. } 1574 \text { member of maschup in } \\
\text { Berufjördur (1567, } 1572 \text { as skipper); } \\
1580 \text { still active there }{ }^{37}\end{array}$ & $\begin{array}{l}\text { 1569-1576 } \\
\text { Berufjörður }\end{array}$ & \\
\hline $\begin{array}{l}\text { Losekanne, Johan } \\
\text { died before c. } 1574\end{array}$ & $\begin{array}{l}\text { brother of Bernd, sailed to Berufjörður } \\
\text { before him (i.e. before 1549) }\end{array}$ & & \\
\hline $\begin{array}{l}\text { Losekanne, Luder } \\
\text { died 9-3-1612 }\end{array}$ & $\begin{array}{l}1572 \text { partner in maschup in Berufjördur } \\
\text { (stays at home) } \\
1597 \text { shipowner in Stykkishólmur }\end{array}$ & & C $1573-1612$ \\
\hline $\begin{array}{l}\text { Losekanne, Marten } \\
\text { Father: Bernd? }\end{array}$ & $\begin{array}{l}1572 \text { partner in maschup; } 1590 \\
\text { merchant in Berufjördur }{ }^{39}\end{array}$ & $\begin{array}{l}\text { 1586-1596 } \\
\text { Berufjörður }\end{array}$ & \\
\hline Lubbe, Johan & 1570-1571 merchant in Búðir ${ }^{40}$ & & \\
\hline $\begin{array}{l}\text { Lude, Claus } \\
\text { died and buried } \\
\text { 3-6-1585, } \\
\text { Helgafell }^{41}\end{array}$ & $\begin{array}{l}\text { Sometime shipowner in Nesvogur? }{ }^{42} \\
1558 \text { in Kumbaravogur? }{ }^{43}\end{array}$ & $\begin{array}{l}1571 \\
\text { Grindavík }\end{array}$ & \\
\hline Luders, Johan & $\begin{array}{l}\text { 1572, } 1576 \text { partner in maschup in } \\
\text { Berufjördur (remains at home) }\end{array}$ & & \\
\hline
\end{tabular}

36 RAK D11 Pakke 25: Declaration of Eiríkur Ârnason, 21 August 1567 (15670821SKR00), in which Losekanne is called "Berndt Martenß".

37 SAB 2-R.11.ff.: Complaint of Bremen against Hamburg presence in Berufjörður, 23 January 1580 (15800123BRE00).

38 SAB 2-R.11.ff.; RAK D11 Pakke 25: Complaint against Oldenburg merchants in Stykkishólmur, 2 November 1597 (15971102BRE00).

39 RAK D11 Pakke 26: Testimonies of Icelanders, 1590 (a. o. 15670821SKR00).

40 SAB 2-R.11.ff.; RAK D11, Pakke 25: Complaints against Hamburg merchants in Búðir, 23 September 1570 and 23 January 1571 (15700923BRE00, 15710123BRE00)

41 According to his gravestone: Pjóðminjasafn Îslands, Reykjavik, inv. no. 6242/1912-17. See also Section 4.5.

42 SAB 2-R.11.ff.: Verdict of the Bremen city council, 3 February 1585 (15850203BRE00)

43 He is mentioned in the debt book of Clawes Monnickhusen (no. 133). Hofmeister, "Schuldbuch 2001", 30. 
Iceland merchants (continued)

\begin{tabular}{|c|c|c|c|}
\hline Name & Career in Iceland & Licences & Other \\
\hline $\begin{array}{l}\text { Meyer, Christoffer } \\
\text { born c. } 1521\end{array}$ & $\begin{array}{l}1539 \text { barber-surgeon; } 1549,1567,1572 \\
\text { partner in maschup in Berufjörður (1572 } \\
\text { remains at home); } 1580 \text { still active in } \\
\text { Berufjörður }{ }^{44} \\
1570-1571 \text { merchant in Búðir }{ }^{45} \\
1585 \text { shipowner in Nesvogur }{ }^{46} \\
\text { see also Shetland }\end{array}$ & $\begin{array}{l}\text { 1577-1585 } \\
\text { Berufjördur }\end{array}$ & \\
\hline $\begin{array}{l}\text { Meyer, Luder } \\
\text { Father: Christoffer? }\end{array}$ & $\begin{array}{l}\text { 1572-1576 partner in maschup in } \\
\text { Berufjördur }\end{array}$ & & \\
\hline Moige, Bartold & c. 1548 in Hólmur & & \\
\hline $\begin{array}{l}\text { Monnickhusen, } \\
\text { Clawes }^{47} \text { I }\end{array}$ & $\begin{array}{l}1552 \text { skipper; }{ }^{48} 1557-1558 \text { merchant in } \\
\text { Kumbaravogur (probably remains at } \\
\text { home, see Clawes II) }\end{array}$ & & \\
\hline $\begin{array}{l}\text { Monnickhusen, } \\
\text { Clawes II } \\
\text { father: Clawes I }\end{array}$ & $\begin{array}{l}\text { 1557-1558 merchant in Kumbaravogur } \\
\text { (stays at home later, } 1578 \text { freighter on } \\
\text { the ship of Johan Munsterman). }{ }^{49}\end{array}$ & & \\
\hline $\begin{array}{l}\text { Munsterman, } \\
\text { Hinrick }\end{array}$ & 1558 in Kumbaravogur? ${ }^{50}$ & & \\
\hline $\begin{array}{l}\text { Munsterman, } \\
\text { Johan } \\
\text { died } 1578\end{array}$ & $\begin{array}{l}\text { c. } 1540-1578 \text { merchant in } \\
\text { Kumbaravogur }^{51}\end{array}$ & $\begin{array}{l}\text { 1567-1579 } \\
\text { Kumbaravogur }\end{array}$ & \\
\hline
\end{tabular}

44 SAB 2-R.11.ff.: Complaint of Bremen against Hamburg presence in Berufjörður, 23 January 1580 (15800123BRE00).

45 SAB 2-R.11.ff.; RAK D11, Pakke 25: Complaints against Hamburg merchants in Búðir, 23 September 1570 and 23 January 1571 (15700923BRE00, 15710123BRE00)

46 SAB 2-R.11.ff.: Verdict of the Bremen city council, 3 February 1585 (15850203BRE00).

47 First name uncertain, not mentioned in the sources: Hofmeister, "Schuldbuch 2001", 29.

48 DI 12:323. This could also be Clawes II.

49 Hofmeister, "Schuldbuch 2001", 24-32.

50 Appears in the debt book of Clawes Monnickhusen (no. 25). Hofmeister, "Schuldbuch 2001", 30. 51 SAB 2-R.11.ff.: Appeal to Joachim Hinck for help in acquiring a licence, 21 October 1570 (15701021BRE00); RAK D11 Pakke 25: Appeal to King Frederick II to allow Munsterman's widow to continue his trade, 9 February 1579 (15790209BRE00); SAB 2-R.11.ff.; RAK D11 Pakke 25: Request for a licence for Neswage, 20 November 1585 (15851120BRE00). 
Iceland merchants (continued)

\begin{tabular}{|c|c|c|c|}
\hline Name & Career in Iceland & Licences & Other \\
\hline Nagel, Bruning & $\begin{array}{l}1558 \text { in Kumbaravogur } \\
1585 \text { shipowner in Nesvogur on behalf of } \\
\text { the archbishop }\end{array}$ & & \\
\hline Oldenbuttel, Johan & $\begin{array}{l}1590 \text { skipper in Berufjördur } \\
1592-1598 \text { sea passes for a "kraffel" or } \\
\text { "rasegel" of } 50 \text { lasts named de Daniel }\end{array}$ & $\begin{array}{l}\text { 1596-1601 } \\
\text { Berufjördur }\end{array}$ & \\
\hline $\begin{array}{l}\text { Oldensche, } \\
\text { Herman }\end{array}$ & $\begin{array}{l}\text { c. } 1548 \text { in Hólmur } \\
\text { Possibly Herman Oldenseel, who was } \\
\text { later active as a Lübeck merchant }{ }^{55}\end{array}$ & & \\
\hline $\begin{array}{l}\text { Osnabrugge, Hans } \\
\text { van }\end{array}$ & 1549 partner in maschup in Berufjördur & & \\
\hline $\begin{array}{l}\text { Osnabrugge, } \\
\text { Hinrick van }\end{array}$ & $\begin{array}{l}\text { 1572-1576 partner in maschup in } \\
\text { Berufjördur }\end{array}$ & & \\
\hline Pundt, Hinrick & 1572 partner in maschup in Berufjördur & & \\
\hline Ratke, Heine & $\begin{array}{l}1569 \text { skipper; }^{56} 1580 \text { skipper in } \\
\text { Kumbaravogur, earlier in Nesvogur }{ }^{57}\end{array}$ & & \\
\hline Rede, Johan van & c. 1548 in Hólmur & & \\
\hline $\begin{array}{l}\text { Reimers, Brun } \\
\text { died 16-9-1594 }\end{array}$ & $\begin{array}{l}1548 \text { freighted cargo on a ship to Hólmur } \\
\text { see also Shetland }\end{array}$ & & C 1548-1593 \\
\hline Reineke, Johan & $\begin{array}{l}\text { 1549, } 1572-1576 \text { partner in maschup in } \\
\text { Berufjörður }\end{array}$ & & \\
\hline Reymels, Clawes & 1558 in Kumbaravogur? ${ }^{58}$ & & \\
\hline Ropsleger, Ropke & c. 1548 in Hólmur & & \\
\hline
\end{tabular}

52 Appears in the debt book of Clawes Monnickhusen (no. 85). Hofmeister, "Schuldbuch" (2001), 30.

53 SAB 2-R.11.ff.: Verdict of the Bremen city council, 3 February 1585 (15850203BRE00)

54 RAK D11 Pakke 26: Testimonies of Icelanders, 1590 (a.o. 15670821SKR00).

55 RAK D11 Pakke 25: Bremen's answer to the complaint of Heinrich Mumme in Berufjörður, 28 February 1567 (15670228BRE00). See also Section 7.2.6.

56 Hertzberg, “Tagebuch”, 36.

57 RAK D11 Pakke 25: Complaints of Johan Munsterman's widow about Joachim Kolling, 1 December 1570 (15801201BRE00); Request to keep trading in Stykkishólmur, 20 April 1597 (15970420BRE00).

58 Appears in the debt book of Clawes Monnickhusen (nos. 4, 5). Hofmeister, "Schuldbuch" (2001), 30. 
Iceland merchants (continued)

\begin{tabular}{|c|c|c|c|}
\hline Name & Career in Iceland & Licences & Other \\
\hline $\begin{array}{l}\text { Salomon, Hinrick } \\
\text { died 30-7-1597 }\end{array}$ & $\begin{array}{l}1569 \text { freighter on the ships of Heine } \\
\text { Ratke and Johan Munsterman } \\
1582 \text { shipowner or merchant in Nesvogur } \\
\text { and Berufjörður } 60\end{array}$ & & C 1562-1597 \\
\hline $\begin{array}{l}\text { Schomaker, } \\
\text { Herman } \\
\text { died } 1600\end{array}$ & $\begin{array}{l}\text { merchant in Grindavík/Keflavík, tried to } \\
\text { acquire a licence in } 1566^{61}\end{array}$ & & $\begin{array}{l}\text { C } 1566 \\
\text { B } 1584\end{array}$ \\
\hline Schroder, Evert & 1587 merchant in Búðir ${ }^{62}$ & & \\
\hline Schroder, Johan & 1580 s skipper in Vatnsleysa ${ }^{63}$ & $\begin{array}{l}1589-1595 \\
\text { Vatnsleysa }\end{array}$ & \\
\hline Schulte, Gert & 1548 freighter of a ship to Hólmur & & C 1532-1565 \\
\hline Slochter, Johan & c. 1548 in Hólmur & & \\
\hline $\begin{array}{l}\text { Staeffhorst, } \\
\text { Meineke }\end{array}$ & $\begin{array}{l}\text { skipper and freighter in Berufjörður } \\
\text { before } 1549\end{array}$ & & \\
\hline Steffens, Frantz & merchant in Hólmur until c. 1548 & & \\
\hline $\begin{array}{l}\text { Stroteman, } \\
\text { Reineke } \\
\text { died before } 1572\end{array}$ & $\begin{array}{l}1567 \text { merchant in Berufjörður }{ }^{64} \\
1572 \text { partner in maschup in Berufjörður } \\
\text { (his widow) }\end{array}$ & & \\
\hline Swachman, Reineke & 1549 partner in maschup in Berufjördur & & \\
\hline Tilebare, Friedrich & 1600 sea pass for a "boott" of 50 lasts & $\begin{array}{l}\text { 1599-1601 } \\
\text { Berufjördur }\end{array}$ & \\
\hline $\begin{array}{l}\text { Tilebare, Gerdt } \\
\text { died before } 1572\end{array}$ & $\begin{array}{l}1549 \text { partner in maschup in Berufjörður, } \\
1572 \text { his widow }\end{array}$ & & \\
\hline Trupe, Hinrich & 1548 freighted cargo on a ship to Hólmur & & C $1534-1544$ \\
\hline Vasmer, Dirick & $1582-1583$ skipper in Nesvogur 65 & & \\
\hline Vasmer, Johan & 1567 merchant in Berufjörður ${ }^{66}$ & & \\
\hline
\end{tabular}

59 Hertzberg, “Tagebuch”, 36-37.

60 RAK D11 Pakke 25: Complaints about Hamburg merchants in Berufjörður, 18 January and 1 February 1582 (15820118BRE00; 15820201BRE00).

61 RAK D11 Pakke 25; SAB 2-R.11.ff.: Requests for licences, 6 September 1565 and 29 March 1566 (15650906BRE00; 15660329BRE00).

62 RAK D11 Pakke 25: Complaints against English pirates, December 1587 (15871200BRE00)

63 SAB 2-R.11.ff.: Instruction for Heinrich Bredelo, 18 January 1588 (15880118BRE00).

64 RAK D11 Pakke 25: Declaration of Eiríkur Árnason, 21 August 1567 (15670821SKR00).

65 SAB 2-R.11.ff.: Request for mediation by the Archbishop, 27 September 1583 (15830927BRE00).

66 SAB 2-R.11.ff.: Complaint by Heran Oldensche about Bremen interference in Berufjörður (15670310KOB00). 
Iceland merchants (continued)

\begin{tabular}{|c|c|c|c|}
\hline Name & Career in Iceland & Licences & Other \\
\hline Wake, Reiner & merchant in Berufjörður before 1549 & & \\
\hline Walleman, Cordt & $\begin{array}{l}1600 \text { merchant in Iceland }{ }^{67} \\
1598-1599 \text { sea passes for a } \\
\text { "rahboyertt" of } 50 \text { lasts named de Katte, } \\
1608,1610-1611 \text { for a "boet" of } 40 / 50 \\
\text { lasts named de Valcke }\end{array}$ & $\begin{array}{l}\text { 1599-1601 } \\
\text { Búdir }\end{array}$ & \\
\hline $\begin{array}{l}\text { Wedeman, Herman } \\
\text { died 4-9-1584 }\end{array}$ & $\begin{array}{l}\text { 1549, } 1552,,^{68} 1572-1576 \text { partner in } \\
\text { maschup in Berufjördur }(1549,1552 \text { as } \\
\text { skipper, } 1572 \text { remains at home })^{69}\end{array}$ & & E 1563 \\
\hline $\begin{array}{l}\text { Wedeman, Luder } \\
\text { born before } 1521\end{array}$ & $\begin{array}{l}1535 \text { first sailing; } 1549,1572-1576 \\
\text { partner in maschup in Berufjörður }\end{array}$ & & \\
\hline $\begin{array}{l}\text { Werenberch, Johan } \\
\text { Father: Herman }\end{array}$ & $\begin{array}{l}1580 \text { requests licence for Ríf and } \\
\text { Nesvogur }\end{array}$ & & \\
\hline Westerwold, Gerdt & $\begin{array}{l}\text { merchant in Hólmur until c. } 1548 \\
\text { see also Shetland }\end{array}$ & & \\
\hline Widen, Lambert tor & merchant in Hólmur until c. 1548 & & \\
\hline Wiggers, Johan & 1576, 1582 merchant in Berufjörður ${ }^{72}$ & & \\
\hline Wilde & 1502 merchant in Arnarstapi? ${ }^{73}$ & & \\
\hline Wilkens, Herman & & $\begin{array}{l}\text { 1599-1601 } \\
\text { Berufjördur }\end{array}$ & \\
\hline $\begin{array}{l}\text { Winters, Reineke } \\
\text { died before } 1572\end{array}$ & $\begin{array}{l}\text { 1549, } 1572 \text { partner in maschup in } \\
\text { Berufjördur ( } 1572 \text { his widow) }\end{array}$ & & \\
\hline Wisseloh, Wend & c. 1575 skipper in Berufjörður & & \\
\hline Wittesant, Clawes & 1558,1570 merchant in Kumbaravogur ${ }^{74}$ & & \\
\hline
\end{tabular}

67 SAB 2-R.11.ff.: Testimonies about weights in Iceland, 30 December 1600 (16001230BRE00). 68 DI 12:323.

69 According to the Bremen Tonnengeldregister (SAB 2-R.2.A.o.2.b.l.), Wedeman transported 5 lasts fish to or from Bremen in 1532 (Hofmeister, "Bremer Kornakzise”, 64). However, it was not indicated where the fish came from.

70 Elderman of the gemene kopman 1558, councillor 1562, d. 21-10-1566.

71 SAB 2-R.11.ff. (15800813BRE00).

72 RAK D11 Pakke 25: Letter of Archbishop Henry III to King Frederick II about Hamburg merchants in Berufjörður, 26 February 1582 (15820226FUR00).

73 DI 8:76; DN 16:338: Bergen complaints about the Icelandic trade, 1502. Not entirely sure if he was from Bremen.

74 SAB 2-R.11.ff: Appeal to Joachim Hinck for help in acquiring a licence, 21 October 1570 (15701021BRE00). Appears in the debt book of Clawes Monnickhusen (nos. 108, 114). Hofmeister, "Schuldbuch 2001", 30. 


\section{Shetland merchants}

\begin{tabular}{|c|c|c|}
\hline Name & Career in Shetland & $\begin{array}{l}\text { Other } \\
\text { functions }\end{array}$ \\
\hline Anteman, Johan & 1572 acquires part in a maschup & \\
\hline Baelen, Cordt van & 1557 crew of Segebad Detken & \\
\hline Balleers, Johan & 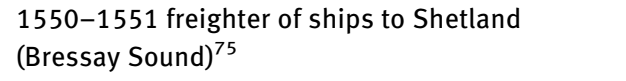 & \\
\hline Barnewolt, Evert & 1557 helmsman of Cordt Hemeling in Whalsay ${ }^{76}$ & \\
\hline Bartscherer, Johan & $\begin{array}{l}1563 \text { receives permission of Queen Mary for } \\
\text { Baltasound; }{ }^{77} \text { in the service of Johan Balleers } \\
\text { before }^{78}\end{array}$ & \\
\hline Beling, Arendt & 1572 acquires part in a maschup & \\
\hline Beling, Johan & $\begin{array}{l}1557 \text { in Shetland } \\
1566 \text { merchant in Uyeasound, where he was } \\
\text { robbed by pirates twice }\end{array}$ & \\
\hline Bicker, Arp & 1557 crew of Johan Ellebracht & \\
\hline Binneman, Reineke & 1557 crew of Johan Ellebracht & \\
\hline Blome, Hinrick & 1557 crew of Segebad Detken & \\
\hline Brede, Eler & 1572 acquires part in a maschup & $\mathrm{BF}$ \\
\hline Brinckman, Carsten & 1572 part in a maschup & \\
\hline Breker, Gerdt & 1557 ship's carpenter in Whalsay / Laxfirth & \\
\hline $\begin{array}{l}\text { Brummer, Hinrick } \\
\text { father: Luder? }\end{array}$ & $\begin{array}{l}1557 \text { crew of Johan Ellebracht } \\
1585 \text { signs debt declaration of Luder Brummer in } \\
\text { Shetland }^{79}\end{array}$ & \\
\hline $\begin{array}{l}\text { Brummer, Luder } \\
\text { died before 16-8-1585 }\end{array}$ & $\begin{array}{l}1557 \text { crew of Johan Ellebracht } \\
1572 \text { acquires part in a maschup } \\
1582-1585 \text { merchant in Shetland } \\
\text { 80 }\end{array}$ & \\
\hline
\end{tabular}

75 Focke, “Seefahrtenbuch”, 99.

76 SAB 2-R.11.kk.: Answer of Gerdt Breker in the case about the death of Cordt Hemeling, 7 February 1558 (15580207BRE00).

77 SAB 2-R.11.kk.: Letter of Queen Mary to Olave Sinclair, 21 September 1563 (15630921EDI00). 78 SAB 2-R.11.kk.: Final plea of Johan Runge against Segebad Detken, 14 December 1562 (15621214BRE00).

79 SAB 2-R.11.kk.: Declaration of Dirick Wencken's widow, 16 August 1585 (15850816BRE00). 80 SAB 2-R.11.kk.: Debt declarations of Luder Brummer, 1582-3 (15820000BRE02; 15820514BRE00; 15830000BRE00). 
Shetland merchants (continued)

\begin{tabular}{|c|c|c|}
\hline Name & Career in Shetland & $\begin{array}{l}\text { Other } \\
\text { functions }\end{array}$ \\
\hline \multicolumn{3}{|l|}{$\begin{array}{l}\text { Bruns, Wichman } \\
\text { died } 1540^{81}\end{array}$} \\
\hline Buckhoren, Johan & 1557 crew of Johan Ellebracht & \\
\hline Cordes, Johan & $\begin{array}{l}\text { 1560-1562 merchant in Baltasound; servant of } \\
\text { Segebad Detken before } \\
1563 \text { receives permission of Queen Mary for } \\
\text { Baltasound }^{83}\end{array}$ & \\
\hline $\begin{array}{l}\text { Detken, Herman } \\
\text { father: Segebad I84 }\end{array}$ & 1602 merchant in Uyeasound & \\
\hline $\begin{array}{l}\text { Detken, Magnus } \\
\text { father: Herman }\end{array}$ & $\begin{array}{l}1604 \text { merchant in Uyeasound } \\
1599-1601,1608 \text { sea passes for a "both" of } 40 \\
\text { lasts named de Engell }\end{array}$ & \\
\hline $\begin{array}{l}\text { Detken, Segebad (I) } \\
\text { died } 1573^{85} \\
\text { buried in Lunda Wick }\end{array}$ & $\begin{array}{l}\text { 1557, 1560-1562 skipper in Baltasound / } \\
\text { Burravoe } \\
1566 \text { skipper in Uyeasound, where he was } \\
\text { robbed twice by pirates }{ }^{87} \\
\text { Part of maschup in Shetland until } 1572\end{array}$ & \\
\hline
\end{tabular}

81 His testament from 1540 suggests that he had been skipper in Shetland. Hofmeister, "Sorgen eines Bremer Shetlandfahrers", 51-52.

82 SAB 2-R.11.kk.: Rejoinder of Segebad Detken in the case about the harbour Baltasound, 10 December 1562 (15621210BRE00).

83 SAB 2-R.11.kk.: Letter of Queen Mary to Olave Sinclair, 21 September 1563 (15630921EDI00).

84 Peter Deetjen and Adolf Deetjen, Die Bremer Familie Deetjen (Bergen, 1908), 81.

85 The year of death on his gravestone, which is heavily weathered and overgrown by lichen, is unreadable. MacDonald, "More Shetland Tombstones", 28-30, 35-36, who transcribed the text from a rubbing in 1934, assumes that Detken died in 1573. This is based on on the text on the stone, which mentions that Detken had sailed to Shetland for 52 years, and on an answer of Detken and his companions in the court case against Johan Runge (SAB 2-R.11.kk., 28 January 1563, 15630128BRE00), in which Detken claimed that he had traded there for about 40 years, which would thus mean that he sailed there for the first time in $c .1522$. In that case his 52nd year would be around 1573. However, the document is unclearly formulated, and could also refer to one of his predecessors in the trade. I follow MacDonald's argument here, with the implication that the skipper with the same name who was active in Shetland from 1583 to 1585 is another person. A Segebad Detken from a third generation received sea passes from 1613 onwards.

86 SAB 2-R.11.kk.: Declaration of Olave Sinclair about the situation in Baltasound, 18 August 1563 (15630818BRA00).

87 SD 1195-1579, no. 158. 
Shetland merchants (continued)

\begin{tabular}{|c|c|c|}
\hline Name & Career in Shetland & $\begin{array}{l}\text { Other } \\
\text { functions }\end{array}$ \\
\hline $\begin{array}{l}\text { Detken, Segebad (II) } \\
\text { died (after) } 1598^{88} \\
\text { father: Segebad I? }\end{array}$ & $\begin{array}{l}\text { 1583-1585, },^{89} 1592 \text { skipper in Shetland } \\
\text { (Baltasound?) }\end{array}$ & \\
\hline Eggers, Hinrick & $\begin{array}{l}1560-1562 \text { part of maschup in Baltasound; } 1563 \\
\text { receives permission from Queen Mary for } \\
\text { Baltasound }^{90}\end{array}$ & \\
\hline Ellebracht, Johan & 1557 skipper in Shetland & \\
\hline Esick, Hinrick & Part of maschup in Shetland until 1572 & $\mathrm{BF}$ \\
\hline Felthusen, Berent & 1557 crew of Segebad Detken & \\
\hline Foege/Voege, Dirick & $\begin{array}{l}1562 \text { skipper in Uyeasound }{ }^{91} \\
1566 \text { skipper in Shetland, where he was attacked } \\
\text { by pirates }\end{array}$ & \\
\hline $\begin{array}{l}\text { Folkers, Cordt } \\
\text { died } 1543\end{array}$ & $\begin{array}{l}1543 \text { probably died on a journey to or from } \\
\text { Shetland } 92\end{array}$ & \\
\hline $\begin{array}{l}\text { Gerbade, Gerdt } \\
\text { died } 1600\end{array}$ & $\begin{array}{l}\text { part of maschup in Shetland until } 1572 \\
\text { see also Iceland }\end{array}$ & E 1568 \\
\hline Grale, Peter & 1557 crew of Johan Ellebracht & \\
\hline Hackman, Johan & 1557 crew of Segebad Detken & \\
\hline Hagen, Johan & 1557 crew of Segebad Detken & \\
\hline Heide, Cordt van der & 1557 crew of Johan Ellebracht & \\
\hline $\begin{array}{l}\text { Hemeling, Cordt } \\
\text { died Shetland, } 1557\end{array}$ & $\begin{array}{l}1557 \text { skipper in Whalsay / Laxfirth, died from } \\
\text { trauma after being wounded by Gerdt Breker } \\
\text { Brother of Gerdt }\end{array}$ & \\
\hline
\end{tabular}

88 Detken made his testament on 14 June 1587 (printed in Deetjen and Deetjen, Die Bremer Familie Deetjen, 81-84), which was copied into the testament register of the city of Bremen upon his death (SAB 2-Qq.4.c.3.b.2.c. Bd. 3). It is included between testaments from July and August 1598, which means that he must have died no earlier than August 1598.

89 SAB 2-R.11.kk.: Debt declarations of Luder Brummer, 1583 (15830000BRE00) and Dirick Wencken's widow, 1585 (15850816BRE00).

90 SAB 2-R.11.kk.: Letter of Queen Mary to Olave Sinclair, 21 September 1563 (15630921EDI00). $91 \mathrm{SAB}$ 2-R.11.kk.: Declaration of Olave Sinclair about the situation in Baltasound, 18 August 1563 (15630818BRA00).

92 Hofmeister, “Sorgen eines Bremer Shetlandfahrers”, 46-51. 
Shetland merchants (continued)

\begin{tabular}{|c|c|c|}
\hline Name & Career in Shetland & $\begin{array}{l}\text { Other } \\
\text { functions }\end{array}$ \\
\hline Hemeling, Gerdt & $\begin{array}{l}1557 \text { skipper in Shetland; } 1567 \text { skipper in a bay } \\
\text { near Sumburgh Head, where his ship was } \\
\text { commandeered by James Hepburn, Earl of } \\
\text { Bothwell, on the latter's flight from Scotland }{ }^{93} \\
\text { brother of Cordt }\end{array}$ & HS 1592 \\
\hline $\begin{array}{l}\text { Hemeling, Johan (“Himmill, } \\
\text { Yain") }\end{array}$ & $\begin{array}{l}1602 \text { inherited debts of Cordt Meyer in } \\
\text { Dunrossness }\end{array}$ & \\
\hline Hilmers, Cordt & 1572 part of maschup & \\
\hline Hoeggers, Hinrick & 1557 crew of Johan Ellebracht & \\
\hline $\begin{array}{l}\text { Holler, Cordt } \\
\text { died } 1610\end{array}$ & 1572 part of maschup & $\begin{array}{l}\text { E } 1581 \\
C \\
1584-1595\end{array}$ \\
\hline Icken, Oltman & 1557 in Shetland & \\
\hline Koster, Hinrick & 1560-1562 part of maschup in Baltasound & \\
\hline Kummertho, Hinrick & c. 1495 merchant in Shetland ${ }^{94}$ & \\
\hline Ladiges, Hinrick & 1560-1562 part of maschup in Baltasound & \\
\hline Luers, Carsten & 1560-1562 part of maschup in Baltasound & \\
\hline Lunsman, Herman & 1557 crew of Johan Ellebracht & \\
\hline Luse, Dirick & 1557 crew of Johan Ellebracht & \\
\hline Meyer, Bartold & 1560-2 part of maschup in Baltasound & \\
\hline Meyer, Christoffer & $\begin{array}{l}1557 \text { sells maschup in Shetland } \\
\text { see also Iceland }\end{array}$ & \\
\hline Meyer, Cordt & 1578 indebted to David Tulloch in Dunrossness & \\
\hline $\begin{array}{l}\text { Meyer, Hilmer (“Meiger, } \\
\text { Humierus") }\end{array}$ & $\begin{array}{l}1566 \text { skipper in Scalloway, where he was robbed } \\
\text { by pirates }\end{array}$ & \\
\hline Meyer, Jacob & 1582 skipper in Shetland ${ }^{95}$ & \\
\hline Michel, Johan & $\begin{array}{l}\text { 1560-1562; } 1566 \text { skipper in Baltasound / } \\
\text { Cullivoe (in } 1566 \text { attacked by pirates) }\end{array}$ & \\
\hline
\end{tabular}

93 SD 1195-1579, pp. 124-125.

94 HR III, 4, no. 68; DI 11:47 (14980405BER00). It is not clear if his skipper Janeke Bollessen also traded in Shetland.

95 SAB 2-R.11.kk.: Debt declarations of Luder Brummer, 1582 (15820000BRE02; 15820514BRE00). 
Shetland merchants (continued)

\begin{tabular}{|c|c|c|}
\hline Name & Career in Shetland & $\begin{array}{l}\text { Other } \\
\text { functions }\end{array}$ \\
\hline Middendorp, Herman & 1557 in Shetland & \\
\hline Minden, Hinrich van & 1551 skipper in Bressay Sound ${ }^{96}$ & \\
\hline Nagel, Clawes & 1557 crew of Johan Ellebracht & \\
\hline Oldenburg, Brun & 1557 in Shetland & \\
\hline Oldenburg, Hinrick & 1557 crew of Johan Ellebracht & \\
\hline $\begin{array}{l}\text { Pestorp, Dirick } \\
\text { died 2-2-1606 }\end{array}$ & part of maschup until 1572 & E 1604 \\
\hline $\begin{array}{l}\text { Reimers, Brun } \\
\text { died 16-9-1594 }\end{array}$ & $\begin{array}{l}\text { part of maschup in Shetland until } 1572 \\
\text { see also Iceland }\end{array}$ & $\begin{array}{l}C \\
1548-1593\end{array}$ \\
\hline Reiners, Johan & $\begin{array}{l}1550 \text { skipper in Shetland, died during shipwreck } \\
\text { on the return journey }{ }^{97}\end{array}$ & \\
\hline Runge, Johan & $\begin{array}{l}\text { 1560-1562 skipper in Baltasound, moved to } \\
\text { Bergen due to competition from Segebad Detken }\end{array}$ & \\
\hline $\begin{array}{l}\text { Schomaker, Frantz } \\
\text { died 24-3-1583 }\end{array}$ & 1572 acquires part in maschup & E 1568 \\
\hline Schroder, Henrick & $\begin{array}{l}1557 \text { sold artillery in Shetland to John } \\
\text { Pennycuke }\end{array}$ & \\
\hline Schroder, Herman & $\begin{array}{l}1566 \text { skipper in Whalsay, where he was robbed } \\
\text { by pirates }\end{array}$ & \\
\hline Schulle, Johan & $\begin{array}{l}1557 \text { crew of Johan Ellebracht } \\
1562 \text { merchant in Burravoe } \\
1572 \text { skipper of maschup }\end{array}$ & \\
\hline $\begin{array}{l}\text { Segelcken, Hinrick } \\
\text { d. Shetland, 25-7-1585 } \\
\text { buried in Lunda Wick }\end{array}$ & $\begin{array}{l}1585 \text { signs a debt declaration of Luder Brummer } \\
\text { on the ship of Segebad Detken }{ }^{101}\end{array}$ & \\
\hline Segelcken, Roloff & $\begin{array}{l}1557 \text { crew of Segebad Detken; } 1560-1562 \text { part } \\
\text { of maschup in Baltasound }\end{array}$ & \\
\hline
\end{tabular}

96 Focke, “Seefahrtenbuch”, 99.

97 Focke, "Seefahrtenbuch”, 99.

98 SD 1195-1579, no. 111.

99 SAB 2-R.11.kk.: Declaration of Olave Sinclair about the situation in Baltasound, 18 August 1563 (15630818BRA00).

100 According to his gravestone: MacDonald, "More Shetland Tombstones", 27-28. See also Section 4.5, footnote 311 for a transcript of the text.

101 SAB 2-R.11.kk.: 16 August 1585 (15850816BRE00) 
Shetland merchants (continued)

\begin{tabular}{|c|c|c|}
\hline Name & Career in Shetland & $\begin{array}{l}\text { Other } \\
\text { functions }\end{array}$ \\
\hline Sprenger, Christoffer & $\begin{array}{l}1560 \text { was accused of having traded illegal goods } \\
\text { in Shetland by Grete Embdeman }{ }^{102} \\
\text { Brother of Hinrick }\end{array}$ & \\
\hline Sprenger, Hinrick & $\begin{array}{l}1557 \text { acquires maschup in Shetland } \\
1560 \text { warrantor for his brother Christoffer, who } \\
\text { had traded illegal goods in Shetland }\end{array}$ & \\
\hline $\begin{array}{l}\text { Steding, Carsten } \\
\text { died 19-5-1597 }\end{array}$ & 1572 part in maschup & $\begin{array}{l}\text { C } 1562 \\
\text { B } \\
1574-1597\end{array}$ \\
\hline Schneman, Tonnies & $\begin{array}{l}1602-1603 \text { merchant in Dunrossness } \\
1592-1605 \text { sea passes for a "kraffell" of } 24 \text { lasts } \\
\text { named dat flegende Pertt or dat Sehpert }\end{array}$ & \\
\hline Schneman, Herman & $\begin{array}{l}1602 \text { merchant in Laxfirth } \\
1600-1601 \text { sea pass for a "wyttschip" of } 28 \text { lasts } \\
\text { named dat Sehepartt }\end{array}$ & \\
\hline Teieman, Luder & 1557 crew of Johan Ellebracht & \\
\hline Vaget, Hinrick & $\begin{array}{l}1560-1562 \text { part of maschup in Baltasound; } 1563 \\
\text { receives permission of Queen Mary for } \\
\text { Baltasound }^{103}\end{array}$ & \\
\hline Volmers, Berwardt & 1572 part of maschup & \\
\hline Westerwold, Gerdt & $\begin{array}{l}1560-1562 \text { part of maschup in Baltasound; } 1563 \\
\text { receives permission of Queen Mary for } \\
\text { Baltasound } \\
\text { see also Iceland }\end{array}$ & \\
\hline Wicherling, Gerdt & 1572 part of maschup & \\
\hline $\begin{array}{l}\text { Wickboldt, Ladewich } \\
\text { died 10-3-1603 }\end{array}$ & 1572 sale of maschup in Shetland & $\begin{array}{l}\text { BF } \\
\text { E } 1573\end{array}$ \\
\hline Wilckens, Alert & 1557 crew of Cordt Hemeling ${ }^{104}$ & \\
\hline Willers, Oldtman & 1572 part of maschup & \\
\hline Wulffers, Johan & 1557 crew of Johan Ellebracht & \\
\hline
\end{tabular}

102 SAB 2-R.11.kk.: Complaint of Grete Embdeman against Hinrick Sprenger, 31 October 1560 (15601031BRE00).

103 SAB 2-R.11.kk.: Letter of Queen Mary to Olave Sinclair, 21 September 1563 (15630921EDI00). 104 SAB 2-R.11.kk.: Answer of Gerdt Breker in the case about the death of Cordt Hemeling, 7 February 1558 (15580207BRE00). 